\title{
Reaching Out: Understanding the Puzzle of Cross-Party Nominations to the Lower United States Federal Courts
}

\author{
Aman McLeod ${ }^{1}$ \\ ${ }^{1}$ Florida Coastal School of Law, Jacksonville, United States \\ Correspondence: Aman McLeod, Florida Coastal School of Law, Jacksonville, FL, United States. E-mail: \\ amcleod@fcsl.edu
}

Received: December 14, 2012 Accepted: January 9, 2013 Online Published: May 30, 2013

doi:10.5539/jpl.v6n2p116

URL: http://dx.doi.org/10.5539/jpl.v6n2p116

\begin{abstract}
Scholars have argued that U.S. presidents use their judicial appointments to advance their political goals. However, on rare occasions, presidents nominate people who are not members of their political party to the judiciary. This study will examine the factors that affect the probability of a cross-party judicial nomination occurring, in order to better understand the goals that presidents are seeking to advance through these unusual actions. Looking at nominations to United States federal circuit courts and district courts between 1977 through 2004, the study finds that, controlling for a number of relevant factors, a greater number of opposition senators from a state and a higher level of electoral competition between the Republican and Democratic parties in a state increase the probability that a president will name someone from outside of his party from that state to a federal court vacancy. The findings support the hypothesis that presidents make cross-party judicial nominations to further their partisan electoral objectives, and as a response to institutional pressure from opposition senators through the use of Senate rules.
\end{abstract}

Keywords: federal judges, partisanship, judicial nominations, president, courts, United States

\section{Introduction}

There is a wealth of evidence indicating that presidents use their power to nominate federal judges to pursue their legislative and administrative goals (Epstein \& Segal, 2005; Gilman, 2002; Goldman, 1997; Sheldon \& Maule, 1997; Sunstein, Schkade, Ellman, \& Sawicki, 2005), and to maintain and expand public support for their political party (Goldman, 1997; Epstein \& Segal, 2005). It is logical that presidents would see judicial nominations as an opportunity to pursue their policy goals, given that federal courts have the power to interpret federal legislation and to invalidate state and federal legislation using the power of constitutional review (Rowland \& Carp, 1996; Songer, Sheehan, \& Haire, 2000). Accordingly, a nomination to one of these powerful, lifetime positions is something that a president can use to influence public or political audiences, and to reward political cooperation, among other things. For example, given that the United States Senate must approve all judicial nominations, presidents have been known to use these nominations to entice key senators to support legislation that is a part of their policy agenda (Goldman, 1997). Evidence also shows that presidents are mindful of the partisan and electoral implications of their nominations, and that they use these nominations to please interest groups and to attract or retain particular segments of the electorate in their coalition (Epstein and Segal, 2005; Scherer, 2005). Goldman (1997) has noted that presidents sometimes try to pursue multiple goals with a single judicial nomination. For example, when President George W. Bush nominated Miguel A. Estrada to the U.S. Court of Appeals for the District of Columbia Circuit in 2001, he nominated an individual who seemed likely to advance his conservative policy agenda on the bench (New York Times, 2001), and whose nomination would appeal to Latinos which are an important segment of the national electorate (Boyer \& Hudson, 2001).

Presidents' use of federal judicial nominations to pursue partisan and policy goals has consequences for policy orientation of the federal judiciary's rulings. Scholars have long understood that a judge's partisan affiliation can help to predict how that judge will decide cases (e.g., Dubois, 1980; Hall \& Brace, 1992; Ulmer, 1962). It is well documented that federal judges nominated by presidents of different parties display different voting patterns across a host of issue areas, with judges appointed by Democratic presidents issuing more politically liberal rulings than their Republican appointed counterparts (Carp \& Rowland, 1983; Goldman, 1966; Songer \& Davis, 1990; 
Sunstein et al., 2005), and that judges' rulings tend to reflect policy preferences of the president that nominated them (Songer \& Ginn, 2002).

Presumably, when presidents nominate someone outside of their political party to the federal courts, they understand that that person will probably be less likely to advance their policy agenda than a person from the same political party if the nominee is confirmed. (Note 1) Despite this fact, presidents have made a surprising number of cross-party nominations to the federal district courts and circuit courts of appeals since the mid-Twentieth Century (Goldman, 1997). Surprisingly, no studies have examined why presidents make cross-party nominations, or looked into the factors that affect the probability that across-party nomination will be made. The lack of research into this question is particularly salient given the significant power to influence policy that federal judges enjoy, and the fact that they have life tenure in their jobs. The aim of this study is to fill this gap in the literature by examining those circumstances that make a president more likely to give these powerful, lifetime positions to their political opponents. This question will be explored by looking at how different institutional situations and different economic, global and partisan conditions affect the likelihood that a president will nominate someone from another political party to the federal bench. A better understanding of the circumstances that make cross-party appointments more likely should shed light on whether or how presidents use nominations to the federal district and circuit courts to purse their policy or partisan goals. The study should also help us to better understand when and why presidents choose bipartisanship and cross-party cooperation as a tactic to achieve their goals.

\section{The Data}

The data set includes 1661 nominations to Art. III federal district courts and to circuit courts of appeals that were submitted to the Senate between 1977 and 2004, which subsumes all such nominations from the start of the Carter administration until the end of George W. Bush's first term. The data exclude all nominations to the district and circuit courts of the District of Columbia, the U.S. Court of Appeals for the Federal Circuit, and all nominations to the district court for Puerto Rico, and all circuit court nominations from Puerto Rico, given that senatorial courtesy does not apply to these nominations (Sollenberger, 2003). The data from 1977-1998 come from the Lower Federal Court Confirmation Database (LFCCD) (Note 2) compiled by Martinek, Kemper and Van Winkle (2002) for use in their study of the U.S. Senate's treatment of nominations to the federal district and circuit courts of appeals (i.e. the lower federal courts). (Note 3) The author also used data from the Yale Law School Library database of federal judicial nominations for data on nominations made from 1999-2004. (Note 4) It is important to note that nominations submitted to the Senate are the subject of the study, as opposed to the number of individuals nominated. Some individuals were nominated by different presidents for different courts, and some nominations were resubmitted after having expired at the end of a Congress following a biennial election. Accordingly, important variables of interest that could affect the party affiliation of the person nominated (e.g., state unemployment and economic growth levels, and the partisan affiliation of the senators from the nominee's home state) might take different values at different times, which makes it important to focus on the party identification associated with each nomination as opposed to the identity of each nominee. U.S. Supreme Court nominations were not included in the study because the selection process for U.S. Supreme Court nominations is fundamentally different than that for appeals court and district court nominations. This is because presidents are much more personally involved in the selection process for Supreme Court nominees than in the process leading to the selection of lower court nominees, and because a Supreme Court nominee's home state senators do not have the power to block Senate consideration of the nomination through the custom of senatorial courtesy (Epstein and Segal, 2005).

Data concerning the partisan affiliation of the nominees came from a database that Prof. Sheldon Goldman maintains on federal judicial nominees that has used in a number studies (e.g. Goldman, 1997; Goldman, Schiavoni, \& Slotnik, 2009) of the federal judicial nomination and confirmation process.

\section{A Partisan Picture of Federal Court Nominations}

Table 1 shows a breakdown of the partisan affiliations of the persons put forward with each nomination:

Table 1. Partisan affiliations of persons put forward in each nomination, 1977-2004

\begin{tabular}{ccc}
\hline Party Affiliation of Nominees & Frequency & Percent \\
\hline Democrat & 711 & 42.8 \\
Republican & 874 & 52.6 \\
Independent/3rd Party & 76 & 4.6 \\
Total & 1661 & 100.0 \\
\hline
\end{tabular}


Table 2 breaks down the number of cross-party nominations by nominating president:

Table 2. Cross-party nominations by president

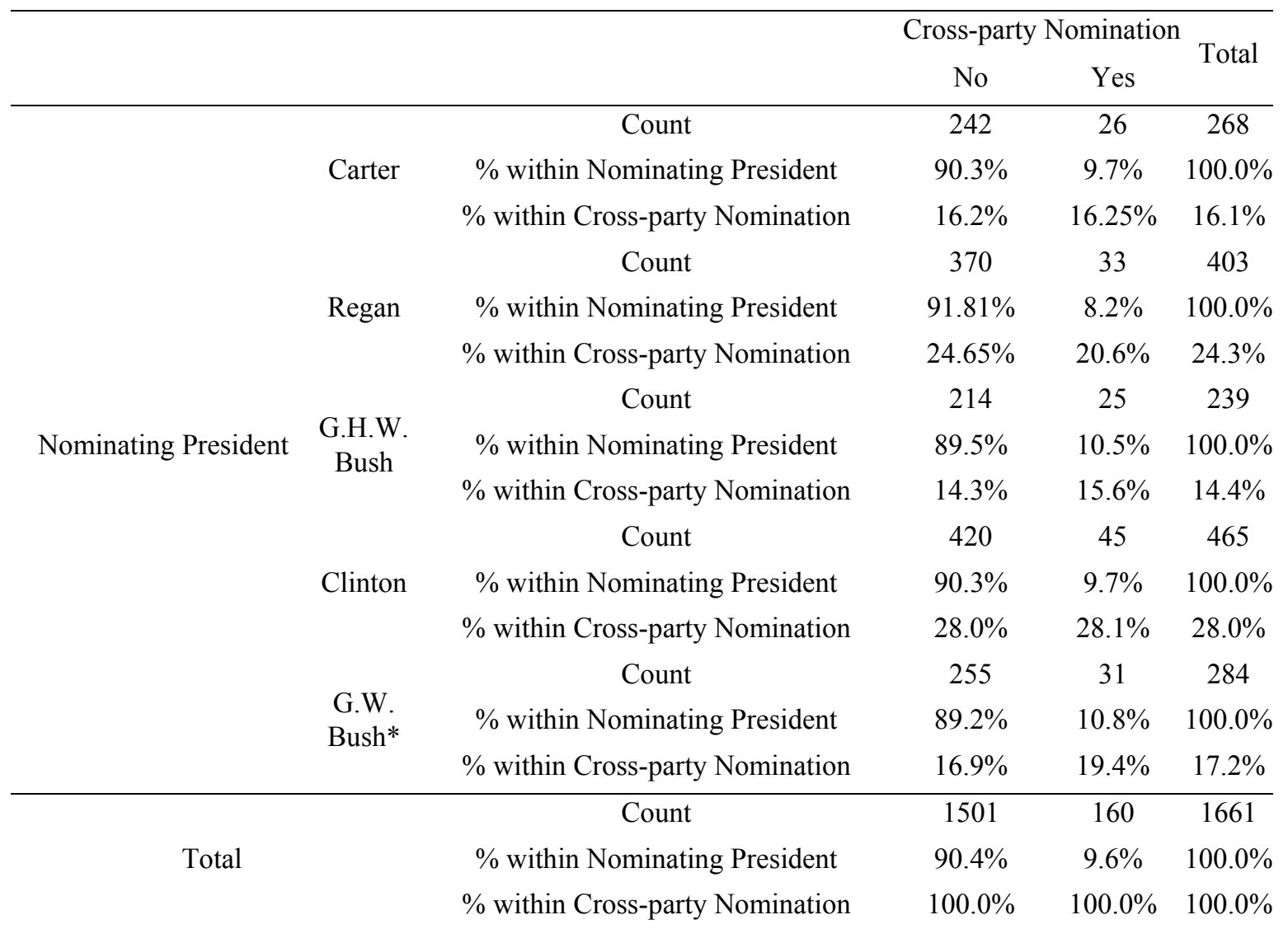

* Opposition assumed control of the Senate approximately three months into his first term, and controlled the chamber for the remainder of the $107^{\text {th }}$ Congress. Cell Percentages are rounded to nearest $.1 \%$

The table shows that Carter made the lowest percentage of his judicial nominations from outside of his party (9.7\%), while George W. Bush (10.9\%) had the highest percentage of cross-party nominations among his nominations to the federal courts. It is worth noting, that one key difference between these two presidencies is that during the first half of Bush's term, the U.S. Senate was controlled either by the opposition or there were an equal number of Democratic and Republican senators, whereas Carter's party controlled the Senate for his entire term. In fact, all of the presidents in the study, except Carter, had to deal with a Senate that was controlled by the opposition for at least a portion of their time in office, which suggests that there might be some relationship between the number of opposition senators and the number of cross-party nominations that presidents make.

Table 3 breaks down cross-party nominations by whether the nominations were made to a seat on a district court or a circuit court of appeals:

Table 3 shows that the vast majority of cross-party nominations were for positions on district courts. One possible explanation for this finding is that when presidents choose to look outside of their parties for judicial nominations, they prefer to make these nominations to the lowest courts in the federal system where, if confirmed, the nominees' rulings will not become binding precedent, and can be reversed on appeal.

However, these tables are very limited in what they can tell us about why presidents make cross-party appointments. In order to better understand what institutional factors impact a president's choice to make a cross-party nomination, it is necessary to estimate a regression model of presidents' nominating decisions that includes independent variables that are believed to affect the probability that a president will make a cross-party appointment. A regression model will also allow us to evaluate the strength and significance of the relationships between the independent and dependent variables, which we cannot do with simple tabulations like those presented in the tables above. 
Table 3. Cross-Party nominations by nomination type

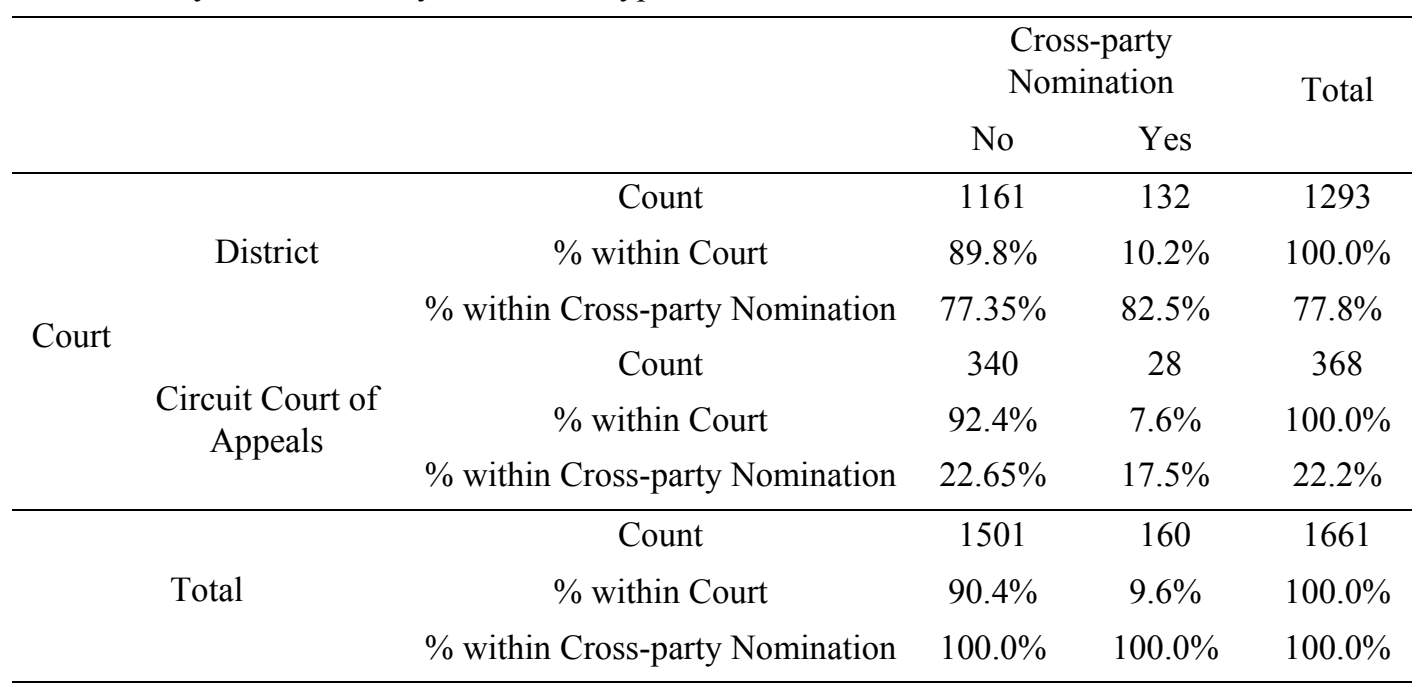

\section{Estimation of the Model and Description of Variables}

The dependent variable, the occurrence of a cross-party nomination, can take only two values, 1 (a cross-party nomination occurred) or 0 (a cross-party nomination did not occur). Accordingly, the model is estimated using a statistical regression technique known as logit, which allows us to assess the effect that each of the independent variables has on the probability that the dependent variable will take the value 1, meaning that a cross-party nomination occurred. Furthermore, in order to account for the fact that nomination decisions by a single president might be related to one another, the model is estimated with standard errors clustered by president.

The study modeled a president's nominating decision controlling for the following variables:

\subsection{Court}

Table 3 shows that a far higher proportion of district court nominations were cross-party than was the case in circuit court nominations. Accordingly, the model includes a variable called Court that is coded 1 if the nomination was to a seat on a circuit court, and 0 if it was to a district court, to test the hypothesis that presidents are more likely to fill a district court vacancy with a cross-party nomination, than a circuit court vacancy.

\subsection{Opposition Senators}

The custom of senatorial courtesy gives senators who are from a nominee's home state a key role in the process of choosing the nominee. According to this custom, the Senate will block any judicial nomination if a senator from the nominee's home state objects (Epstein \& Segal, 2005). One study by Slotnick (1980) found that although senators rarely made formal use of their power to block nominations, they frequently used the threat of blocking a nomination to influence the selection of the eventual nominee. Goldman (1997) reports that President Harry Truman, a Democrat, felt fewer impediments to nominating Republicans if they were from states that did not have any Democratic senators, since there was no Democratic senator to block such a nomination. Furthermore, studies by Massie, Hansford \& Songer (2004) and Binder and Maltzman (2004) show that judicial vacancies are filled more swiftly when a state is represented by senators from the president's party controlling for certain factors, , which suggests that opposition senators might use senatorial courtesy to delay nominations in order to affect whom the president nominates. From this evidence, it is here hypothesized that the probability that the president will make a cross-party nomination will rise as the number of opposition senators from the nominee's home state increases, given that the presence of each opposition senator increases the chance that a home state senator will use senatorial courtesy to pressure the president into nominating someone from an opposition party. This hypothesis is operationalized by the inclusion of a variable called Number of Opposition Senators from Nominee's Home State. This variable is coded 2, 1, or 0 depending on the number of opposition senators representing the nominee's home state at the time of the nomination.

\subsection{Opposition Senate Control}

Table two, presented above, and previously published studies suggest that when an opposition party has had a majority in the Senate, the opposition has used its control of the Senate's agenda, especially the Senate Judiciary Committee, to pressure the president to make a cross-party nomination (George, 1999; Goldman, 1997; Goldman 
\& Slotnick 1999; Rutkus, 2008). In order to test the hypothesis that opposition control of the senate increases the incidence of cross-party nominations, the model will include the variable Opposition Senate Control, that will be coded 1 if the nomination was made at a time when an opposition party controlled the Senate, and 0 if otherwise.

\subsection{State Party Electoral Competition and First Term}

It has been argued that presidents evaluate the relative strength of their party in individual states when deciding when, where and how to use their political resources in order to win elections (see e.g., Shaw, 1999; 1999b), and that presidents use their bureaucratic (e.g., Brown, 1982) and judicial nominations (e.g., Epstein and Segal) to influence elections. Furthermore, in the legislative context, Trubowitz and Mellow (2005) have found that there were more bipartisan votes on bills in the U.S. Congress when the Democratic and Republican parties were more competitive nationally than in periods when each party faced little competition within its regional base. This finding supported Trubowitz and Mellow's hypothesis that in times of greater regional polarization, the two major parties would shun legislative compromise in favor of stronger appeals to their regional bases and party activists, but that both parties were more likely to compromise when they were competitive across the nation in order to appeal to more moderate voters. If one extrapolates Trubowitz and Mellow's (2005) findings to the presidential context, it is plausible to assume that presidents might try to enhance the popularity of their party by giving a judicial nomination to people who are not members of their political party when presidents perceive that their political party is in close competition with other political parties in a state. The hypothesis that presidents have been influenced by the relative strength of the two major parties when nominating federal judges can be controlled for by including a variable to measure the relative level of electoral competitiveness between the two major political parties in a given state during the year that nomination is submitted. In his book, Party Strength in the United States, Paul David (1972) devised a measure of party electoral strength in a state in a given year that is the average of the percentage of votes that the party's candidates received in the most recent U.S. House, U.S. Senate and gubernatorial election. (Note 5) Here, the comparative electoral strength of the two major parties in a state in a given year is controlled for using the variable called Electoral Competition in the Nominee's Home State. This variable is coded as the absolute value of the difference between their party electoral strength scores. For example, if the two major parties where equal in their electoral success in a state, the value of this variable would be 0 , while the value of the variable would be 1 if one of the major parties received all of the votes for all of the relevant elections that comprise this measure. If presidents are taking the level of major party competition into account when making nominations to federal district and circuit courts, it is here hypothesized that they will be more likely to make a cross-party nomination as the value of the state party competition variable decreases toward 0 . The study also includes a variable, First Term, to account for whether the nomination took place during the president' first term. This variable was included in order to account for the fact that the need to run for reelection might induce a president to consider how a nomination might further his own political needs as opposed to those of his political party, given that these are not always necessarily the same (e.g., Schlesinger, 2004). The variable as coded as 1 if the nomination was made during a president's first term, and 0 if otherwise.

\subsection{State Economic Conditions}

Trubowitz and Mellow (2005) also found that bipartisan votes in Congress were also correlated with economic conditions. Specifically, they found that the incidence of bipartisan votes was inversely correlated with the lagged national unemployment rate, (Note 6) but was positively correlated with the rate of growth in the gross domestic product from one congress to another. The authors hypothesized that positive economic conditions (i.e., strong economic growth and low unemployment) make it less necessary for parties to appeal to their respective economic bases, and make it easier for them to cooperate across a range policies. Adapting this hypothesis to the context of lower court federal judicial nominations, this study includes variables to control for state economic conditions. Specifically, the study includes a variable called Nominee's State Unemployment that represents the lagged monthly seasonally adjusted unemployment rate for the state, and another variable, Nominee's State GDP Growth, representing the growth rate of the state's GDP in constant 2011 dollars for the year preceding the nomination. If good economic conditions encourage cross-party nominations, the sign of the lagged state unemployment variable should be negative, while the sign of the state GDP variable should be positive.

\subsection{International Crises}

There is evidence that international crises also affect the prevalence of bipartisan cooperation in Congress. Specifically, Trubowitz and Mellow found that the number of international crises that occurred in a given year increased the incidence of bipartisan votes in Congress. This study also controls for the effect of international crises on the incidence of cross-party appointments, and uses a similar definition of a crisis that was used by Trubowitz and Mellow. They defined an international crisis as an instance in which U.S. military forces were 
deployed abroad. That definition is used here, and is taken from data gathered by the Congressional Research Service (Grimmett, 2011). The variable representing the occurrence of these crises is called International Crises in the Nomination Year, and it is coded as the number of international crises that occurred in the year in which a nomination took place. If international crises encourage bipartisan behavior, this variable should have a positive sign.

Table 4 shows the results of the estimated model:

Table 4. General model of cross-party nominations

\begin{tabular}{ccccccc}
\hline Variable & Coefficient & Standard Error & $\mathrm{Z}$ & $\mathrm{P}>|\mathrm{z}|$ & \multicolumn{2}{c}{$[95 \%$ Conf. Interval $]$} \\
\hline Court & -.324582 & .312121 & -1.04 & 0.298 & -.936328 & .2871639 \\
Opposition Senate Control & -.0998906 & .2275491 & -0.44 & 0.661 & -.5458787 & .3460974 \\
$\begin{array}{c}\text { Number of Opposition Senators from } \\
\text { Nominee's Home State }\end{array}$ & .2634397 & .1007136 & 2.62 & 0.009 & .0660446 & .4608347 \\
$\begin{array}{c}\text { Electoral Competition in Nominee's } \\
\text { Home State }\end{array}$ & -.9161094 & .319177 & -2.87 & 0.004 & -1.541685 & -.290534 \\
First Term & -.1551692 & .1414085 & -1.10 & 0.273 & -.4323248 & .1219865 \\
Nominee's State Unemployment & -.014766 & .0877746 & -0.17 & 0.866 & -.186801 & .1572691 \\
Nominee's State GDP Growth & -.7030021 & 1.161328 & -0.61 & 0.545 & -2.979162 & 1.573158 \\
International Crises in Nomination Year & .0240428 & .0186137 & 1.29 & 0.196 & -.0124394 & .0605249 \\
Constant & -2.180685 & .6528544 & -3.34 & 0.001 & -3.460256 & -.9011137 \\
\hline
\end{tabular}

Log pseudo-likelihood $=-520.59198$

Pseudo $\mathrm{R}^{2}=0.0111$

\section{Analysis of Results}

Overall, these results vary dramatically from those that were predicted. Surprisingly, opposition control of the Senate does not exert any significant influence (i.e. significance $<.1$ ) on the likelihood that a cross-party nomination will occur. Also, whether the nomination is made to a district court or to a circuit court, as well as state economic conditions and the occurrence of international crises do not seem to influence a president's decision to look outside of his party for a nominee when other factors are controlled for. Table four shows that the only two variables that seem to exert some significant influence on the probability of a cross-party nomination are those controlling for the number of opposition senators from the nominee's home state, and the variable representing the level of competition between the two major parties in the nominee's home state. Furthermore, both of these variables have the predicted sign. In more concrete terms, the results show that for each additional opposition senator from a nominee's state, the probability of a cross-party nomination increases by $2.2 \%$, while a $1 \%$ increase in the absolute difference of the electoral competition scores of the two major parties leads to an $7.7 \%$ decrease in the probability of a cross-party nomination, if all other factors are held at their means.

The most important result of this study is the evidence that it provides suggesting how electoral considerations play an important role in determining who presidents nominate to the lower federal benches. The fact that a cross-party nomination was more likely from a state where the two major parties were in close competition supports Trubowitz and Mellow's (2005) hypothesis that displays of bipartisanship, in this case in the form of a cross-party judicial nomination, are more likely in states where neither major party enjoys a clear electoral advantage over the other, and where it seems possible to appeal to more moderate voters by showing a willingness to work with members of the other party. Also, given the fact that the First Term variable was not significant, it appears that presidents are more influenced by the level of competition between their party and the other major party in state and congressional elections, and the effect that cross-party nominations will have in states where this competition is relatively more intense, and are less concerned about whether these nominations are made before or after their own reelection campaigns. None of the other variables that Trubowitz and Mellow (2005) found to be predictors of bipartisan votes in Congress that were brought into this study, specifically those accounting for state economic conditions and the number of international crises during the year of the nomination, appeared to affect the likelihood of a cross-party appointment. Overall, these results emphasize how important cross-party nominations 
are as a tool to enhance the president's party's appeal in states where the two parties are in close competition, and how much attention presidents pay to the level of partisan competition at the state level.

Another important insight revealed by these concerns how the Senate impacts the judicial nomination process. Take, for example, the fact that the variable Opposition Senate Control does not appear to have a statistically significant effect on the occurrence of a cross-party nomination. This suggests that despite the enormous power that the opposition has to block a president's judicial nominations when it controls the Senate, it does not use this power to force presidents to name members of the opposition to the lower federal courts and that opposition party leaders, when they control the Senate, eldom use their control of the Senate's agenda to influence nominations. Rather, the significance of the Number of Opposition Senators from Nominee's Home State variable confirms the findings of other scholars that individual opposition senators prefer to use their power to slow down the process of nomination (e.g., Binder and Maltzman, 2004) and confirmation (Binder and Maltzman, 2002; Goldman, 2003; Hartley \& Holmes, 2002; Martinek et. al. 2002), regardless of which party controls to the Senate, to try to influence presidents to nominate their political allies to the lower federal courts. Also, the results indicate that whether the vacancy is on a district court or circuit court has no effect on the probability that a president will fill the vacancy with a cross-party nomination. Apparently, party competition in the nominee's home state and the influence of senators from that state have a greater influence on presidents nominating decisions, than the possibility that a political opponent will use the greater relative power of a circuit court seat to act against a president's partisan preferences.

\section{Conclusion}

These data confirm the widely held assumption that presidents see federal district and circuit court nominations as important opportunities to pursue their partisan and policy agendas. The results also show that although presidents normally pursue these agendas by nominating someone from their own party, they will reach outside of their parties for nominees when doing so suits their political ends. The results also confirm the long posited thesis that individual senators play an influential role in determining who is nominated to district and circuit courts.

In light of the finding that presidents appear to use federal court nominations to appeal to the electorate, an important question that remains unanswered regards the extent to which presidents are nominating people who will be hostile to their policy agenda when they reach the bench. The question is as follows: is it possible that when presidents make cross-party nominations, they tend to choose people outside of their party who have policy views that are similar to their own? For a president to find a cross-party nominee who agrees with that president on many policy issues would be a logical thing to do, since it would allow the president to reap the political benefits of a cross-party nomination, while still placing a political ally on the bench. Mitchell H. Cohen's nomination to the federal district court of New Jersey in 1962 is an example of a cross-party nomination that might fit this description. Cohen was a Republican, but one with close personal ties to prominent Democrats in New Jersey. Cohen's name was recommended to Attorney General Robert Kennedy by the President of the American Bar Association (ABA), Bernard Segal. Although Segal was a Republican and Kennedy was a Democrat, Kennedy and Segal were friends, and Kennedy convinced his brother, President John F. Kennedy, to nominate Cohen (Cohen, 2009). There is evidence that President Kennedy was attempting to use judicial nominations to entice Republican senators to support elements of his legislative agenda, and that Kennedy wanted to maintain the good will of the ABA because of the influential role that it played in the judicial confirmation process (Cohen, 2009). However, it is also possible that Cohen was nominated, not simply because he was a Republican, but, in part, because he was thought to be a Republican who was ideologically left leaning, like most Democrats, especially in light of the strong support that Cohen's nomination received from New Jersey Democrats. Currently, there are no studies comparing the voting records of cross-party nominated judges with same- party nominated judges in order to see whether all judges nominated by presidents of the same party have broadly similar ideologies. Such studies would contribute to our knowledge of whether presidents, when making cross-party nominations, try ensure that they do not nominate people who will frequently oppose their policy agendas once elevated to the bench.

\section{Acknowledgements}

The author would like to thank Prof. Sheldon Goldman, Prof. Wendy Martinek, Rachel Scarlata, Prof. Peter Trubowitz and Colleen Washburn for their assistance in assembling the data for this paper.

\section{References}

Binder, S. A., \& Maltzman, F. (2002). Senatorial Delay in Confirming Federal Judges, 1947-1998. American Journal of Political Science, 46, 190-199. http://dx.doi.org/10.2307/3088422 
Binder, S. A., \& Maltzman, F. (2004). The Limits of Senatorial Courtesy. Legislative Studies Quarterly, 29, 5-22. http://dx.doi.org/10.3162/036298004X201078

Biskupic, J. (1997, September 14). Hill Republicans Target 'Judicial Activism' - Conservatives Block Nominees, Threaten Impeachment and Term Limits. Washington Post, p. A1.

Boyer, D., \& Hudson, A. (2001, November 21). GOP charges 'profiling' of Hispanic Nominee. Washington Times, p. A1.

Brown, R. G. (1982). Party and Bureaucracy from Kennedy to Reagan. Political Science Quarterly, 97, 279-294. http://dx.doi.org/10.2307/2149479

Carp, R. A., \& Rowland, C. K. (1983). Policymaking and Politics in the Federal District Courts. Knoxville, TN: University of Tennessee Press.

Cohen, M. (2009). Cross-party Federal Judicial Appointment and President Kennedy's Appointment of U.S. District Judge Mitchell H. Cohen. (unpublished paper available from this author).

David, P. T. (1972). Party Strength in the United States, 1872-1970. Charlottesville, VA: University of Virginia Press.

Dubois, P. L. (1980). From Ballot to Bench: Judicial Elections and the Quest for Accountability. Austin, TX: University of Texas Press.

Epstein, L., \& Segal, J. A. (2005). Advice and Consent: The Politics of Judicial Appointments. Oxford, UK: Oxford University Press.

George, H. T. (1999, January 27). Clinton Nominates Justice Durham to the Federal Bench. The Columbian, p. B5

Gilman, H. (2002). How Political Parties Can Use the Courts to Advance Their Agendas: Federal Courts in the United States, 1875-1891. American Political Science Review, 96, 511-524.

Goldman, S. (1966). Voting Behavior on the United States Courts of Appeals, 1961-1964. American Political Science Review, 60, 374-83. http://dx.doi.org/10.2307/1953364

Goldman, S. (1997). Picking Federal Judges: Lower Court Selection from Roosevelt through Reagan. New Haven, CT: Yale University Press.

Goldman, S. (2003). Assessing Judicial Confirmation Process: The Index of Obstruction and Delay. Judicature, $86,251-57$.

Goldman, S., \& Slotnick, E. (1999). Picking Judges under Fire. Judicature, 82, 265-284.

Goldman, S., Schiavoni, S., \& Slotnick, E. (2009). W. Bush’s Judicial Legacy. Judicature, 92, 258-288.

Grimmett, R. F. (2011). Instances of Use of United States Armed Forces Abroad, 1798-2010. Washington, DC: Congressional Research Service.

Hall, M. G., \& Brace, P. (1992). Toward and Integrated Model of Judicial Voting Behavior. American Politics Quarterly, 29, 147-168. http://dx.doi.org/10.1177/1532673X9202000201

Hartley, R. E., \& Holmes, L. M. (2002). The Increasing Scrutiny of Lower Federal Court Nominees. Political Science Quarterly, 117, 259-278. http://dx.doi.org/10.2307/798183

Hudson, A. (2002, May 10). Senate GOP Marks Year of Blocked Nominations. Washington Times, p. A4.

Martinek, W. L., Kemper, M., \& Van Winkle, S. R. (2002). To Advise and Consent: The Senate and Lower Federal Court Nominations, 1977-1998. Journal of Politics, 64, 337-361. http://dx.doi.org/10.1111/1468-2508.00129

Massie, T. D., Hansford, T. G., \& Songer, D. R. (2004). The Timing of Presidential Nominations to the Lower Federal Courts. Political Research Quarterly, 57, 145-154.

New York Times (Editorial). (2001, May 11). Battle for the Court. New York Times, p. 34.

Rottinghaus, B. (2006). Rethinking Presidential Responsiveness: The Public Presidency and Rhetorical $\begin{array}{llllll}\text { Convergence, 1953-2001. Journal of } & \text { Politics, } & 68,732 .\end{array}$ http://dx.doi.org/10.1111/j.1468-2508.2006.00457.x

Rowland, C. K., \& Carp, R. A. (1996). Politics and Judgment in the Federal District Courts. Lawrence, KS: Univ. Kansas Press. 
Rutkus, D. S. (2008). Role of Home State Senators in the Selection of Lower Federal Court Judges. Washington, DC: Congressional Research Service (CRS).

Scherer, N. (2005). Scoring Points: Politicians, Activists, and the Lower Federal Court Appointment Process. Stanford, CA: Stanford University Press.

Schlesinger, R. (2004). Riding Coattails: How the Presidential Election Will - Or Will Not - Affect Congressional Races. Campaigns \& Elections, 25, 17-19.

Shaw, D. R. (1999a). The Methods behind the Madness: Presidential Electoral College Strategies, 1988-1996. Journal of Politics, 61, 893-913. http://dx.doi.org/10.2307/2647547

Shaw, D. R. (1999b). Erratum: The Methods behind the Madness: Presidential Electoral College Strategies, 1988-1996. Journal of Politics, 66, 611-615.

Sheldon, C. H., \& Maule, L. S. (1997). Choosing Justice: The Recruitment of State and Federal Judges. Pullman, WA: Washington State University Press.

Slotnick, E. E. (1980). Reforms in Judicial Selection: Will They Affect the Senate's Role (pt. 1). Judicature, 64, 60-73.

Sollenberger, M. A. (2003). The History of the Blue Slip in the Senate Committee on the Judiciary, 1917-Present. Washington, DC: Congressional Research Service.

Songer, D. R., \& Davis, S. (1990). The Impact of Party and Region on Voting Decisions on the US Courts of Appeals. Western Political Quarterly, 43, 317-334. http://dx.doi.org/10.2307/448369

Songer, D. R., \& Ginn, M. H. (2002). Assessing the Impact of Presidential and Home State Influences on Judicial Decision Making in the United States Courts of Appeals. Political Research Quarterly, 55, 299-328.

Songer, D. R., Sheenhan, R. S., \& Haire, S. B. (2000). Continuity and Change on the United States Courts of Appeals. Ann Arbor, MI: Univ. of Michigan Press.

Sunstein, C. R., Schkade, D., Ellman, L. M., \& Sawicki, A. (2005). Are Judges Political? An Empirical Analysis of the Federal Judiciary. Washington, DC: Brookings Institution Press.

Trubowitz, P., \& Mellow, N. (2005). “Going Bipartisan:” Politics by Other Means. Political Science Quarterly, 120, 433-453. http://dx.doi.org/10.1002/j.1538-165X.2005.tb00553.x

Ulmer, S. S. (1962). The Political Party Variable in the Michigan Supreme Court. Journal of Public Law, 11, 352-362.

\section{Notes}

Note 1. Goldman (1997) points out that presidents vary considerably in the amount of attention that they devote to the judicial selection process. However, Goldman's study shows that all presidents establish the broad guidelines that govern the workings of the selection process in their administrations in terms of desired characteristics of potential nominees and relations with the U.S. Senate. Also, all presidents personally make the final decision on all nominations.

Note 2. The data are available at http://cdp.binghamton.edu/ (June 12, 2009).

Note 3. This dataset contains all but twenty-nine nominations from that period. These were excluded because the race of the nominees could not be ascertained from the available sources, and the race of each nominee was an independent variable in Martinek et. al.'s (2002) statistical analysis. Martinek et al. (2002) did not record which nominations they excluded. However, communications with Martinek about the excluded observations and the results of the study that she co-authored have not revealed anything systematic in the excluded nominations that would bias results of the present study.

Note 4. Available at http://judges.law.yale.edu/ (December 11, 2012).

Note 5. David (1972) noted that this measure of party strength was the most appropriate of the various measures of party strength for scientific purposes.

Note 6. The unemployment data are lagged by one congressional session.

\section{Copyrights}

Copyright for this article is retained by the author(s), with first publication rights granted to the journal.

This is an open-access article distributed under the terms and conditions of the Creative Commons Attribution license (http://creativecommons.org/licenses/by/3.0/). 